\title{
FUNKCJONOWANIE SKLEPÓW OSIEDLOWYCH ORAZ ZACHOWANIA ZAKUPOWE I PRZESTRZENNE ICH KLIENTÓW. PRZYKLAD TEOFILOWA W LODZI
}

\begin{abstract}
Zarys treści: Przedmiotem tego opracowania jest funkcjonowanie sklepów osiedlowych w przestrzeni wielkomiejskiej na przykładzie Teofilowa w Łodzi. Uwzględniono przy tym zachowania zakupowe i przestrzenne klientów tych sklepów. Cel pracy stanowi określenie warunków i mechanizmów funkcjonowania sklepów osiedlowych w przestrzeni wielkomiejskiej oraz właściwości struktury i zachowań ich klientów.
\end{abstract}

Słowa kluczowe: sklepy osiedlowe, zachowania zakupowe i przestrzenne klientów, przestrzeń wielkomiejska, Łódź.

\section{Wprowadzenie}

Przemiany społeczno-gospodarcze w Polsce po 1989 roku wiążą się z dynamicznym rozwojem i przeobrażeniami strukturalnymi handlu detalicznego w wielkich miastach. Głównie dzięki inwestycjom zagranicznym w przestrzeni wielkomiejskiej pojawiły się wielkopowierzchniowe placówki handlowe. Ich powstanie przyczyniło się do zmiany preferencji zakupowych klientów sklepów osiedlowych. Wskutek silnej konkurencji dużych obiektów handlowych małe sklepy osiedlowe traciły na znaczeniu, w związku z tym zmniejszała się także ich liczebność. Obecnie w ośrodkach wielkomiejskich na tereny osiedli mieszkaniowych coraz częściej wkraczają małe sklepy sieciowe. Jednocześnie regres ekonomiczny przeżywają małe sklepy osiedlowe należące do osób fizycznych.

Problematyka tej pracy dotyczy w głównej mierze roli sklepów osiedlowych w kształtowaniu przestrzeni wielkomiejskiej. Szczegółowej analizie podlegały nie tylko lokalizacja i funkcje tych placówek, ale także specyficzne cechy ich działalności handlowej, obejmujące m.in. asortyment, jakość i ceny oferowanych produktów, jak też zachowania zakupowe i przestrzenne oraz opinie klientów. Podstawowe zagadnienia badawcze poprzedzono omówieniem położenia geograficznego i historii oraz zagospodarowania przestrzennego obszaru badań. 
Przedmiotem tego opracowania jest funkcjonowanie sklepów osiedlowych w przestrzeni wielkomiejskiej, rozpatrywane na przykładzie zespołu osiedlowego Teofilów w Łodzi. Uwzględniono przy tym zachowania zakupowe i przestrzenne oraz opinie klientów tych sklepów. Zakres badań, prowadzonych w latach 2012-2014, został ograniczony do sklepów osiedlowych, za które przyjęto położone na terenie osiedli mieszkaniowych Teofilowa sklepy detaliczne o powierzchni całkowitej poniżej $400 \mathrm{~m}^{2}$, wyspecjalizowane przede wszystkim w sprzedaży produktów żywnościowych codziennego użytku. Wyróżniają się one zarówno małą powierzchnią sprzedażową, jak i niewielkim zapleczem magazynowym. Ponadto personel i klienci tych sklepów znają się wzajemnie, przy czym ekspedientom znane są upodobania stałych klientów. Podmiot badań reprezentują 24 sklepy osiedlowe znajdujące się na terenie jednostki osiedlowej Teofilów ${ }^{1}$, jak również ich klienci. Jednostka ta, położona w północno-zachodniej części Łodzi, tworzy w większości zespół zabudowy wielorodzinnej, reprezentujący układ przestrzenny odrębny pod względem geograficzno-historycznym, funkcjonalnym i społecznym. Jej granice przebiegają zgodnie z granicami obszaru Teofilowa wydzielonego w jednolitym Systemie Informacji Miejskiej². Celem tej pracy jest określenie warunków i mechanizmów funkcjonowania sklepów osiedlowych w przestrzeni wielkomiejskiej oraz właściwości struktury i zachowań ich klientów. Zmierzano także do ustalenia szans i zagrożeń w rozwoju badanych sklepów osiedlowych.

Literatura przedmiotu wykorzystana w tym opracowaniu odnosi się m.in. do współczesnych tendencji rozwojowych i przekształceń struktury przestrzennej sektora usługowego, a zwłaszcza działalności handlowej w Polsce (Daszkowska 1998, 2005; Rogoziński 2000; Ilnicki 2009; Rudawska 2009; Mikołajczyk, Stolecka 2009; Kucharska 2010) oraz w samej Łodzi (Dzieciuchowicz 2005, 2012, 2013). Odwołano się również do badań z zakresu marketingu terytorialnego usług (Kramer 2000; Czuba 2001; Boguszewicz-Kreft 2009; Szromik 2010; Williamson, Mullin 2011) i zachowań konsumentów (Mazurek-Łopacińska 2003; Światowy 2006; Woś, Rachocka, Kasperek-Hoppe 2011; Rudnicki 2012), a także prac poświęconych lokalizacji działalności gospodarczej, w szczególności handlowej (Szulce 1998; Budner 2003, 2004; Godlewska 2001, 2005; Wilk 2001; Wieloński 2004). Wykorzystane zostały również opracowania omawiające historię Łodzi i samego obszaru badań (Baranowski, Fijałek 1980; Sygulski 2003, 2006; Liszewski 2009; Dzieciuchowicz 2011, 2014).

\footnotetext{
${ }^{1}$ Jednostki osiedlowe zostały wydzielone na obszarze Łodzi dla celów statystycznych w 1978 roku. Są one odpowiednikiem pojedynczych osiedli mieszkaniowych lub ich zespołów (urbanistycznych jednostek bilansowych). Granice tych jednostek ustalono w oparciu o kryteria urbanistyczne, funkcjonalne i historyczno-geograficzne.

${ }^{2}$ Zgodnie z Uchwałą Nr LVI/1069/05 Rady Miejskiej w Łodzi z dnia 26.10.2005 roku dotyczącą Systemu Informacji Miejskiej (SIM), granice obszaru Teofilowa (obszar nr 45) przebiegają wzdłuż ulic Szczecińskiej i Aleksandrowskiej, torów PKP oraz granicy dzielnicy (delegatury) Bałuty i Polesie.
} 
Praca ta bazuje na różnorodnych materiałach dokumentacyjnych i pozyskanych w toku badań terenowych. Materiały dokumentacyjne obejmują dokumentację statystyczną, kartograficzną, prawną, planistyczną i archiwalną. Z badań terenowych pochodzą materiały zgromadzone $\mathrm{w}$ wyniku przeprowadzonych ankiet i wywiadów kwestionariuszowych z klientami badanych sklepów osiedlowych oraz inwentaryzacji tych obiektów handlowych i ich otoczenia (Woźniak 2013).

\section{Położenie geograficzne i historia zespołu osiedli na Teofilowie}

\subsection{Położenie geograficzne osiedli}

Zgodnie z regionalizacją fizyczno-geograficzną Polski, opracowaną przez J. Kondrackiego (2002), teren jednostki osiedlowej Teofilów, podobnie jak całej Łodzi, leży w mezoregionie Wysoczyzny Łaskiej, położonej na zachód od Wzniesień Łódzkich. Natomiast według podziału A. Dylikowej (1973) osiedla Teofilowa znajdują się na Wyżynie Łódzkiej, którą wyróżniają najwyższe na Niżu Polskim wysokości bezwzględne dochodzące do $288 \mathrm{~m}$ n.p.m. Warto też zauważyć, że przez te osiedla przebiega strefa głównego w kraju działu wodnego pomiędzy dorzeczami Wisły i Odry.

Zespół osiedlowy Teofilów znajduje się w północno-zachodniej części Łodzi (rys. 1), na terenie delegatury Urzędu Miasta Łodzi - Bałuty i dzielnicy urbanistycznej Teofilów-Żabieniec oraz jednostki pomocniczej Teofilów-Wielkopolska. W skład tego zespołu wchodzi pięć powojennych osiedli mieszkaniowych, zawartych w granicach czterech, przylegających do siebie obrębów geodezyjnych (rys. 2): obrębu B-43 (osiedle im. W. Reymonta), B-42 (osiedle im. S. Żeromskiego), B-41 ( osiedle im. M. Konopnickiej) oraz B-40 (osiedla Rogatka i Grabieniec). Dominuje tam blokowa zabudowa wielorodzinna, z wyjątkiem osiedla Grabieniec, które skupia zabudowę jednorodzinną (głównie segmentową).

Analizowany zespół osiedli ma korzystne położenie komunikacyjne. Został on zlokalizowany na zewnątrz linii kolei obwodowej, przy ważnej arterii przelotowej - ul. Aleksandrowskiej, która stanowi fragment drogi krajowej nr 72 (KoninŁódź-Rawa Mazowiecka). Ulica ta umożliwia połączenie całego zespołu osiedlowego transportem publicznym i prywatnym ze śródmieściem i innymi dzielnicami miasta. Przebiega nią szereg linii tramwajowych (nr 2, 8 i 13) i autobusowych (78, 78A, 81, 84, 87, 89, 96). Łącząc poszczególne osiedla Teofilowa, ważną funkcję komunikacyjną dla mieszkańców spełnia też ul. Rojna - równoległa do ul. Aleksandrowskiej. Funkcjonują tam linie komunikacji autobusowej (78, 78A, 96) zapewniające osiedlom wewnętrzne i międzydzielnicowe połączenia komunikacyjne. Podobną rolę pełnią też inne linie autobusowe przebiegające przez centrum Teofilowa $(6,76,83)$. Teofilów obsługują również nocne linie autobusowe (N1, N3) oraz bezpłatne linie autobusowe kilku hipermarketów. Dodajmy, że przy jego wschodniej granicy jest usytuowany dworzec kolejowy Łódź-Żabieniec. 


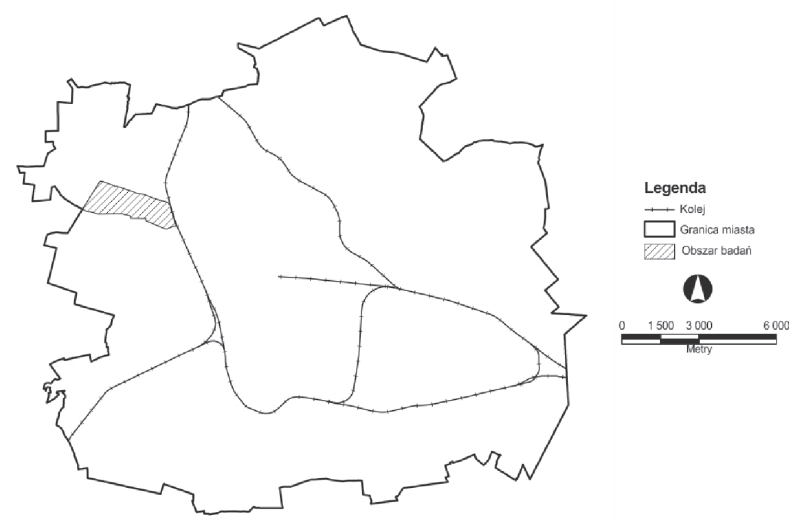

Rys. 1. Położenie jednostki osiedlowej Teofilów w Łodzi Źródło: opracowanie własne

Otoczenie Teofilowa jest zróżnicowane pod względem historyczno-geograficznym i urbanistycznym. Od północy z tym zespołem osiedlowym graniczy dzielnica przemysłowo-magazynowa - Teofilów Przemysłowy. Wzdłuż wschodniej granicy Teofilowa biegnie linia kolejowa, do której od wschodu przylega osiedle wielorodzinne Wielkopolska. Natomiast zachodnie otoczenie Teofilowa tworzą tereny zabudowy jednorodzinnej, zieleni i rolnicze.

\subsection{Historia i zagospodarowanie terenu Teofilowa}

Historia terenu współczesnego Teofilowa jest bogata (Baranowski, Fijałek 1980; Sygulski 2003, 2006; Koter 2012; Badziak, Chylak, Łapa 2014), determinując jego układ przestrzenny, a także samo rozmieszczenie i funkcjonowanie sklepów osiedlowych. W zabudowie mieszkaniowej osiedli Teofilowa, pochodzącej w głównej mierze z lat 60. XX wieku, przeważają czteropiętrowe bloki. Zwraca też uwagę dość dobrze rozwinięta infrastruktura techniczna i społeczna osiedli. Obecnie osiedla te zamieszkuje ok. 39 tys. osób.

Teofilów wyróżnia się rozbudowaną infrastrukturą techniczną i społeczną. W przypadku infrastruktury technicznej zwraca uwagę zarówno dobrze rozwinięta sieć uzbrojenia technicznego, jak też ulic osiedlowych i parkingów. Infrastrukturę społeczną reprezentuje sieć szkół, przedszkoli, żłobków, ośrodków zdrowia i aptek oraz różnorodnych placówek handlowych i usługowych. Poza tym infrastrukturę społeczną wzbogacają kościoły, domy kultury, galerie, dom dziecka i liczne obiekty rekreacyjne: boiska sportowe, klub sportowy (KS „Elta”), kort tenisowy, pływalnia ,Wodny Raj”, parki, zieleńce, ogródek jordanowski, ogródki działkowe. 


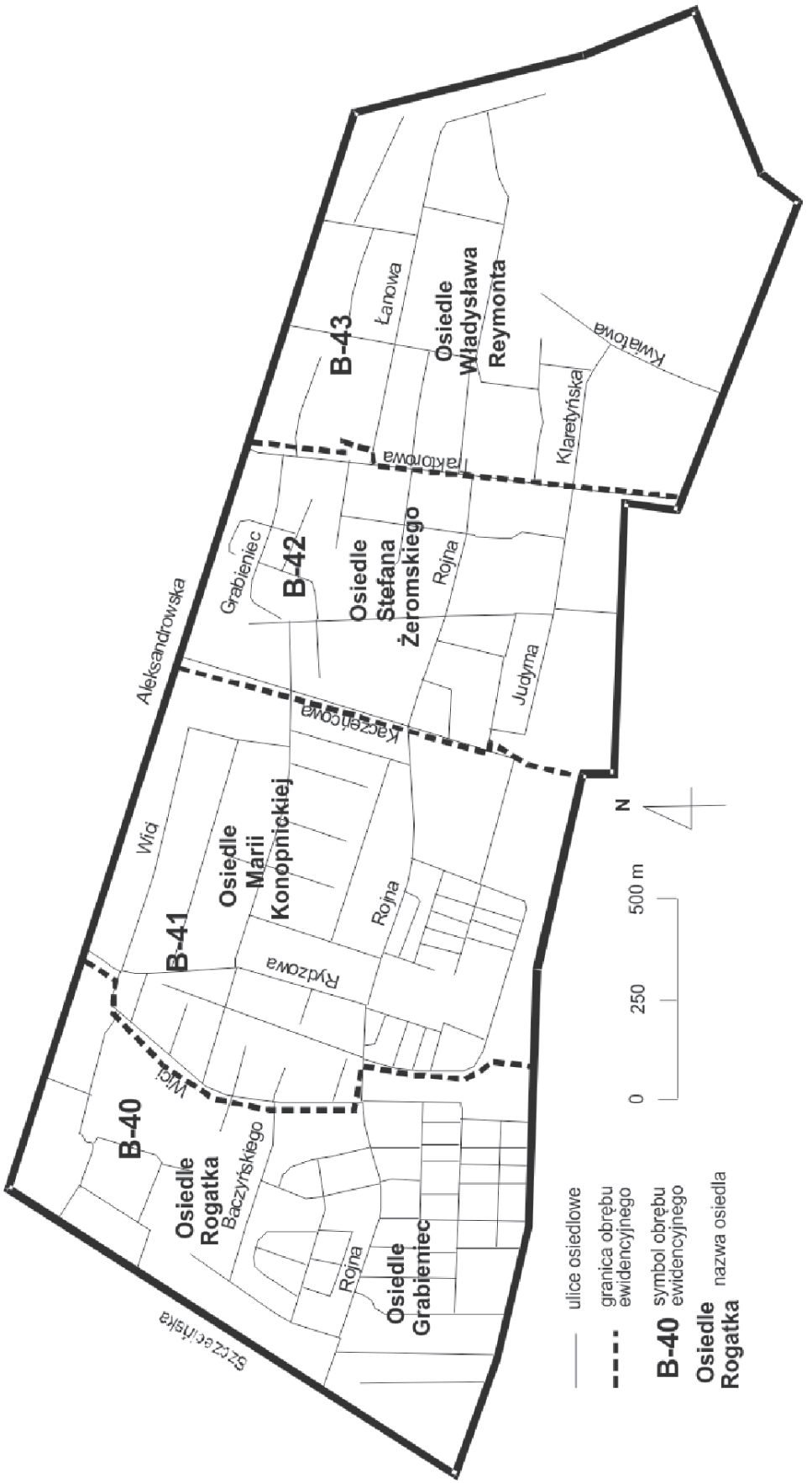

Rys. 2. Podział Teofilowa na obręby ewidencyjne i osiedla mieszkaniowe Źródło: opracowanie własne 
Ożywienie handlu i usług na analizowanym obszarze nastąpiło dopiero w okresie transformacji. Obecnie działalność handlowo-usługowa jest tam prowadzona w ok. 300 lokalach użytkowych ${ }^{3}$.

\section{Lokalizacja sklepów osiedlowych na Teofilowie}

Lokalizacja pozostaje ważną cechą obiektu handlowego w różnych etapach jego funkcjonowania (Budner 2003, 2011; Chwałek 2008). Wybór tej lokalizacji nabiera jednak szczególnego znaczenia podczas zakładania danego sklepu. Jest ona najkorzystniejsza wówczas, gdy walory i wymogi lokalizacyjne są do siebie najlepiej dopasowane (Wieloński 2004). Od wyboru lokalizacji sklepu zależą związane z jego budową nakłady inwestycyjne oraz późniejsze funkcjonowanie.

Analiza położenia sklepu w przestrzeni miejskiej wiąże się z określeniem jego lokalizacji ogólnej i szczegółowej (Szulce 1998; Wilk 2001; Chwałek 2008; Kucharska 2010). Lokalizacja ogólna odnosi się do umiejscowienia sklepu w wyodrębnionym obszarze miasta (dzielnica, osiedle mieszkaniowe). Tymczasem lokalizacja szczegółowa dotyczy konkretnego miejsca (działki gruntowej, obiektu, lokalu użytkowego), w którym znajduje się sklep.

$\mathrm{Na}$ lokalizację sklepów wpływa wiele różnych czynników. Ze względu na zasięg przestrzennego oddziaływania, wyróżnia się czynniki lokalizacji ogólnej tych obiektów handlowych, oddziałujące w skali krajowej i regionalnej, a także czynniki ich lokalizacji szczegółowej o zasięgu lokalnym i miejscowym (Kaczmarek 2010). Wyłącznie w skali krajowej na lokalizację sklepów wywiera wpływ polityka handlowa państwa, stabilność polityczna i gospodarcza oraz stabilność prawna inwestowania. Równocześnie w skali krajowej i regionalnej zaznacza się oddziaływanie takich czynników, jak koszty siły roboczej, bliskość placówek otoczenia biznesu, bliskość siedziby przedsiębiorstwa (sieci), lokalizacja centrów logistycznych, bliskość granicy państwowej, bliskość źródeł zaopatrzenia. Jednocześnie na lokalizację ogólną w skali krajowej i regionalnej, jak również na lokalizację szczegółową w skali lokalnej ma wpływ liczba (koncentracja) ludności, siła nabywcza konsumentów, ich struktura demograficzna i preferencje zakupowe, bliskość szlaków transportowych, ceny gruntów lub dzierżawy i polityka władz samorządowych. Wyłącznie na lokalizację szczegółową w skali lokalnej i miejscowej oddziałuje dostępność komunikacji publicznej i indywidualnej, nastawienie mieszkańców do lokalizacji, oddziaływanie na lokalny układ komunikacyjny i rynek pracy oraz lokalne środowisko przyrodnicze. Rozważane czynniki lokalizacyjne w większości odnoszą się zarówno do dużych przedsiębiorstw handlowych (sieci), jak również mniejszych sklepów.

Sklepy osiedlowe na Teofilowie zostały zlokalizowane w każdym z jego czterech obrębów ewidencyjnych (tab. 1), przy czym liczba tych sklepów w jednym

\footnotetext{
${ }^{3}$ http:// www.smteofilow.com.pl/.
} 
obrębie zawiera się w wąskim przedziale od 5 do 7 . Można zauważyć, że różnice w zasobach ludnościowych pomiędzy poszczególnymi obrębami znajdują odbicie w dostępności sklepów osiedlowych, mierzonej liczbą ludności przypadającej na jeden sklep. Pod tym względem najkorzystniejsza sytuacja występuje w zachodnich osiedlach Teofilowa, gdzie na jeden sklep osiedlowy przypada tylko 913 osób. Dla odmiany najniższą dostępnością odznaczają się sklepy osiedlowe na terenie osiedla im. S. Żeromskiego, gdzie rozpatrywany wskaźnik dostępności wzrasta aż do 2310 osób. Inaczej kształtuje się zasięg przestrzennego oddziaływania sklepów osiedlowych, określony wskaźnikiem powierzchni terenu obsługiwanego przez jeden sklep. Jego wysokie wartości, przekraczające 16 ha, cechują zachodnią i środkową część Teofilowa. Najniższą wartość, równą 10 ha, wskaźnik ten uzyskał dla osiedla im. M. Konopnickiej.

Tabela 1

Sklepy osiedlowe na terenie Teofilowa wg stanu z lipca 2013 roku

\begin{tabular}{|c|c|c|c|c|c|}
\hline $\begin{array}{c}\text { Obręby } \\
\text { ewidencyjne }\end{array}$ & $\begin{array}{c}\text { Powierzch- } \\
\text { nia w ha }\end{array}$ & $\begin{array}{c}\text { Liczba } \\
\text { ludności }\end{array}$ & $\begin{array}{c}\text { Liczba } \\
\text { sklepów }\end{array}$ & $\begin{array}{c}\text { Liczba } \\
\text { ludności } \\
\text { na 1 sklep }\end{array}$ & $\begin{array}{c}\text { Powierzch- } \\
\text { nia na } \\
\text { 1 sklep w ha }\end{array}$ \\
\hline B-43 & 97,53 & 10211 & 7 & 1459 & 13,93 \\
\hline B-42 & 96,68 & 13861 & 6 & 2310 & 16,11 \\
\hline B-41 & 59,89 & 10319 & 6 & 1720 & 9,98 \\
\hline B-40 & 83,80 & 4567 & 5 & 913 & 16,76 \\
\hline Razem & $\mathbf{3 3 7 , 9 0}$ & $\mathbf{3 8 9 5 8}$ & $\mathbf{2 4}$ & $\mathbf{1 6 2 3}$ & $\mathbf{1 4 , 0 8}$ \\
\hline
\end{tabular}

Źródło: materiały zebrane przez A. Woźniak (2014); opracowanie własne.

$\mathrm{Na}$ Teofilowie można wyróżnić trzy typy lokalizacji sklepów osiedlowych (rys. 3). Do pierwszego typu należą sklepy zlokalizowane na terenie czterech kompleksów handlowo-usługowych, które wyodrębniły się w północno-wschodniej części osiedla im. W. Reymonta, na osiedlu im. S. Żeromskiego przy ul. Aleksandrowskiej, w środkowej części osiedla im. M. Konopnickiej oraz przy skrzyżowaniu ul. Traktorowej i Rojnej. W pawilonach handlowo-usługowych znajdują się tam sklepy spożywcze, przemysłowe i wielobranżowe, drogerie, apteki, piekarnie, kwiaciarnie, restauracje i bary, banki oraz usługi rzemieślnicze (fryzjerskie, krawieckie). Dodajmy, iż do niektórych pawilonów przylega rynek warzywno-owocowy. Skupieniom tych placówek handlowych i usługowych są przypisane korzyści wynikające ze wspólnej lokalizacji, stymulujące wzrost obrotów. Sklepy osiedlowe są tam zmuszone do konkurencji z innymi punktami handlowymi. Ten typ lokalizacji reprezentuje ponad połowa sklepów osiedlowych. Drugi typ lokalizacji cechuje sklepy osiedlowe wchodzące w skład niewielkich skupień placówek handlowych (2-4) położonych przy głównych węzłach i trasach komunikacyjnych Teofilowa. W skład takich skupień wchodzą zarówno 


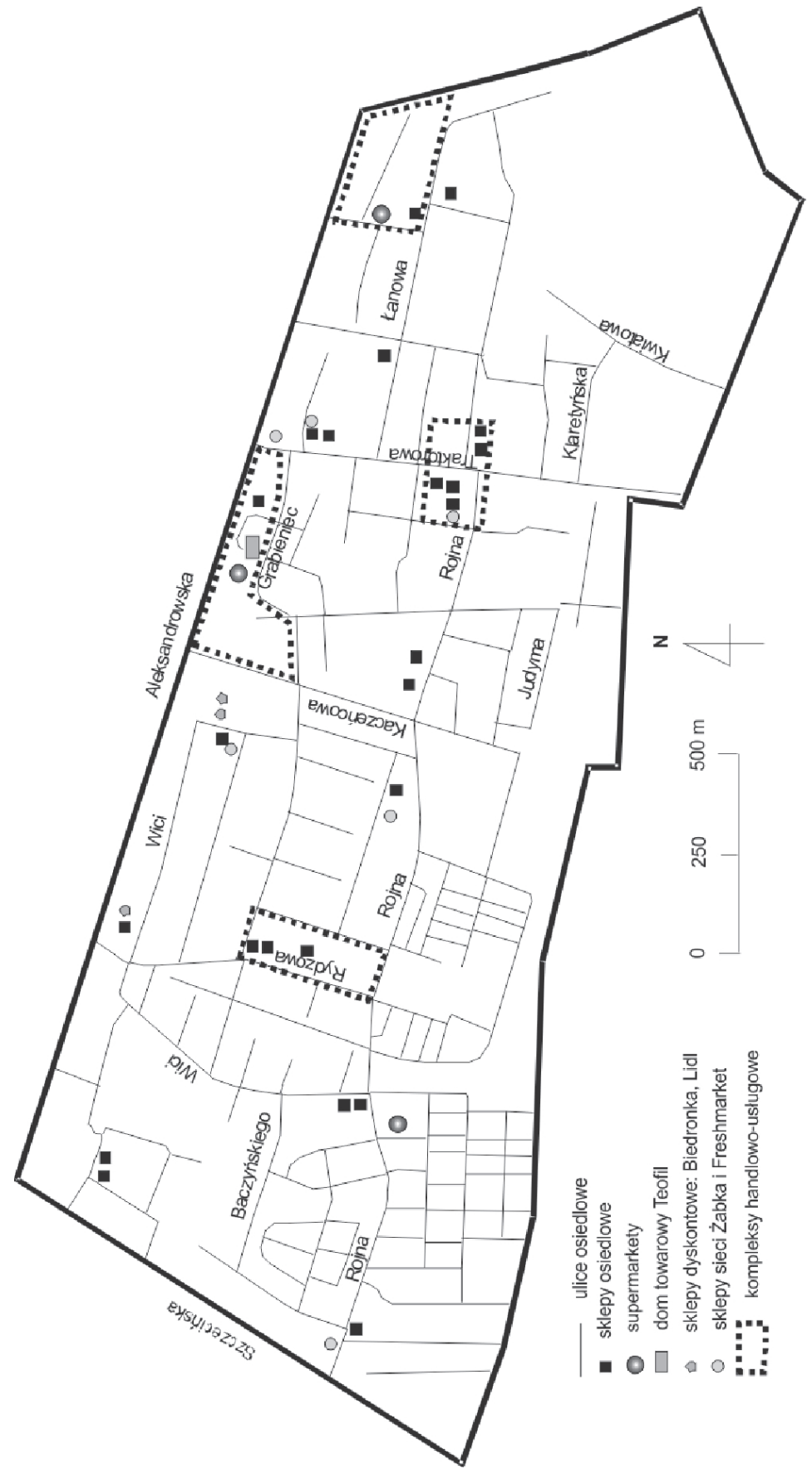

Rys. 3. Sieć handlowa Teofilowa

Źródło: materiały zebrane przez A. Woźniak (2014); opracowanie własne 
supermarkety, jak też sklepy dyskontowe oraz małe sklepy sieciowe (np. Żabka, Fresk Market). Typ ten jest dość słabo rozpowszechniony $(<20 \%$ sklepów). Nieco liczniejsze są natomiast pozostałe sklepy osiedlowe, należące do trzeciego typu lokalizacji - odosobnionej (rozproszonej). Są one usytuowane z dala od innych placówek handlowych i usługowych. Funkcjonowanie tych sklepów ułatwia brak w ich pobliżu konkurencyjnych placówek. Dla odmiany silną konkurencję dla wszystkich analizowanych sklepów osiedlowych stanowią dwa hipermarkety (Carrefour, Tesco) zlokalizowane w pobliżu Teofilowa.

\section{Funkcjonowanie sklepów osiedlowych na Teofilowie}

\subsection{Struktura sklepów osiedlowych Teofilowa według okresu funkcjonowania, form prawno-własnościowych i wielkości}

Funkcjonowanie sklepów osiedlowych na Teofilowie podlega wielu regulacjom prawnym. Ustawa o swobodzie działalności gospodarczej ${ }^{4}$ określa m.in. warunki umożliwiające założenie sklepu. Za odbiór lokalu i decyzję zatwierdzającą spełnienie odpowiednich norm sanitarnych odpowiada miejscowa stacja sanitarno-epidemiologiczna, której uprawnienia określa ustawa o bezpieczeństwie żywności i żywienia ${ }^{5}$. Obydwie wymienione wyżej ustawy precyzują warunki umożliwiające rozpoczęcie działalności gospodarczej i zatrudnianie pracowników sklepów. Odrębne przepisy dotyczą sprzedaży detalicznej alkoholi ${ }^{6}$, prowadzonej przez zdecydowaną większość badanych placówek handlowych. Zezwolenie na taką sprzedaż jest udzielane przez prezydenta miasta. Właściciel każdego sklepu osiedlowego jest również zobowiązany do podpisania umów z dostawcami określonych mediów i firmy wywożącej śmieci, a także uzyskania opinii dotyczącej wentylacji pomieszczeń, aktualnych badań wody i złożenia w miejscowym Urzędzie Skarbowym zaświadczenia o liczbie i miejscu użytkowania kas rejestrujących.

Sklepom osiedlowym na Teofilowie jest przypisanych wiele cech zmiennych, do których należy m.in. okres prowadzenia działalności, formy prawno-własnościowe, zajmowana powierzchnia, liczba pracowników. Typowa długość okresu prowadzenia działalności przez omawiane sklepy wynosi 12 lat, natomiast obszar zmienności tego okresu osiąga aż 46 lat. Przytoczona dominanta okresu działalności sklepów dowodzi doniosłej roli okresu transformacji gospodarczej w kreowaniu sieci tych placówek. Starsze sklepy często były zakładane w latach 70 .

${ }^{4}$ Ustawa z dnia 19 grudnia 2008 roku o zmianie ustawy o swobodzie działalności gospodarczej oraz o zmianie niektórych innych ustaw (tekst jednolity), Dz. U., 2009, nr 18, poz. 97, z 2011 roku nr 131, poz. 764.

${ }^{5}$ Ustawa z dnia 25 sierpnia 2006 roku o bezpieczeństwie żywności i żywienia, Dz. U., 2006, nr 171, poz. 1225 z późn. zm.

${ }^{6}$ Ustawa z dnia 26 października 1982 roku o wychowaniu w trzeźwości i przeciwdziałaniu alkoholizmowi (tekst jednolity), Dz. U., 2007, nr 70, poz. 473 z późn. zm. 
i 80. XX wieku. Są to w głównej mierze obiekty spółdzielcze. Najdłużej działający sklep sieci Społem, zlokalizowany przy ul. Traktorowej (49), został oddany do użytku jeszcze w 1966 roku, tj. w początkowej fazie budowy badanego zespołu osiedlowego. Natomiast najnowszy prywatny sklep osiedlowy, położony przy ul. Rojnej (89), został uruchomiony w 2012 roku. Sklepy zakładane w różnych okresach są odmiennie rozmieszczone (rys. 4). Starsze placówki, prowadzące działalność przez ponad 15 lat, skupiają się bardziej we wschodniej niż zachodniej części Teofilowa, przy czym można zauważyć, że pierwsza z nich jest lepiej wyposażona w infrastrukturę społeczną.

W strukturze prawno-własnościowej rozpatrywanych sklepów, ukształtowanej w wyniku prywatyzacji handlu i usług po 1989 roku, dominują niewielkie placówki handlowe (12) należące do osób fizycznych. Niezależnie od liczby pracowników są one własnością jednego właściciela, co zapewnia samodzielność w prowadzeniu działalności handlowej, a także minimalizację kosztów ponoszonych przez firmę. Drugą, pod względem liczebności, formę własnościową sklepów reprezentują duże placówki handlowe tworzące spółki cywilne (6), które wyróżnia swoboda kształtowania umów spółki i możliwość dowolnej formy opodatkowania. Niewielka część analizowanych sklepów (4) należy do Powszechnej Spółdzielni Spożywców „Społem”. Jej działalność reguluje status spółdzielni, której majątek stanowi prywatną własność dobrowolnie zrzeszonych członków. O zarządzaniu sklepami decyduje w tym przypadku zarząd spółdzielni. Jedynie dwa sklepy osiedlowe są własnością spółek jawnych, które odznaczają się dużym kapitałem początkowym, co korzystnie rzutuje na możliwości ich rozwoju.

Analizowane sklepy różnią się znacznie pod względem zajmowanej powierzchni całkowitej. Do kategorii najmniejszych placówek o powierzchni 50-99 $\mathrm{m}^{2}$ należy pięć sklepów, znajdujących się najczęściej w budynkach wolnostojących (rys. 5). Niewielka powierzchnia tych placówek wymusza tradycyjną, obsługową formę sprzedaży. Powierzchnię od 100 do $199 \mathrm{~m}^{2}$ zajmuje osiem sklepów, najczęściej położonych w budynkach handlowo-usługowych. Sklepy te stosują różne formy sprzedaży. W przypadku pięciu sklepów o powierzchni 200-299 $\mathrm{m}^{2}$ przeważa sprzedaż samoobsługowa. Z reguły są to lokale wbudowane. Powierzchnia sześciu największych sklepów przekracza $300 \mathrm{~m}^{2}$ (maks. $320 \mathrm{~m}^{2}$ ). Większa część z nich, będących własnością spółdzielczą, nie podlegała dotychczas szerszej modernizacji. Warto też zauważyć, że powierzchnia sprzedażowa stanowi nie mniej niż połowę powierzchni całkowitej tych sklepów. Zazwyczaj z powierzchni magazynowej wydzielone są pomieszczenia biurowe i gospodarcze. Ogólnie biorąc, udział powierzchni sprzedażowej w powierzchni całkowitej sklepów osiedlowych maleje wraz z ich powierzchnią całkowitą. Warto zauważyć, iż duże sklepy o powierzchni powyżej $200 \mathrm{~m}^{2}$ najczęściej są zlokalizowane w kompleksach handlowo-usługowych. Natomiast mniejsze obiekty handlowe cechuje silniejsza dekoncentracja. 


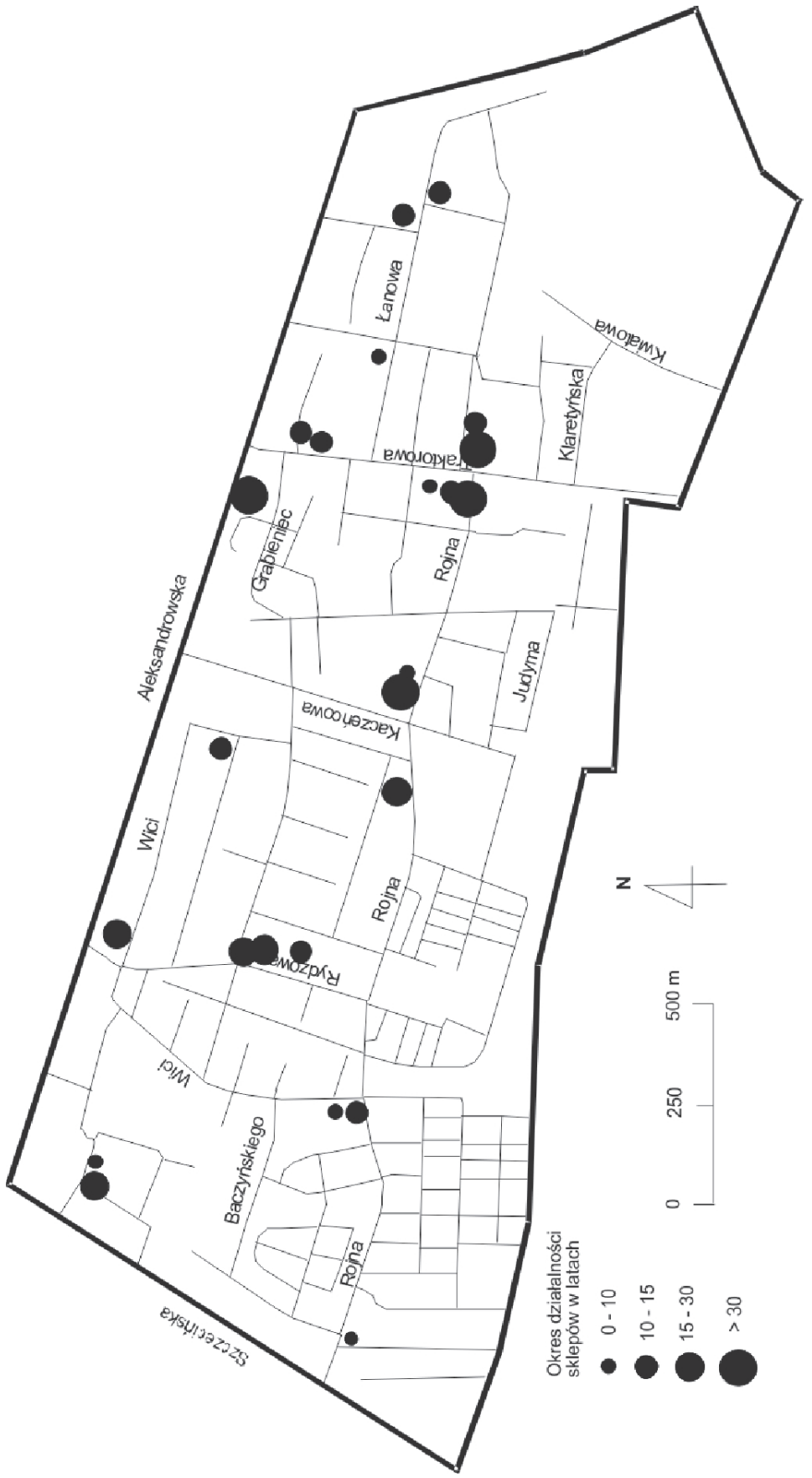

Rys. 4. Okres działalności sklepów osiedlowych na Teofilowie Źródło: materiały zebrane przez A. Woźniak (2014); opracowanie własne 


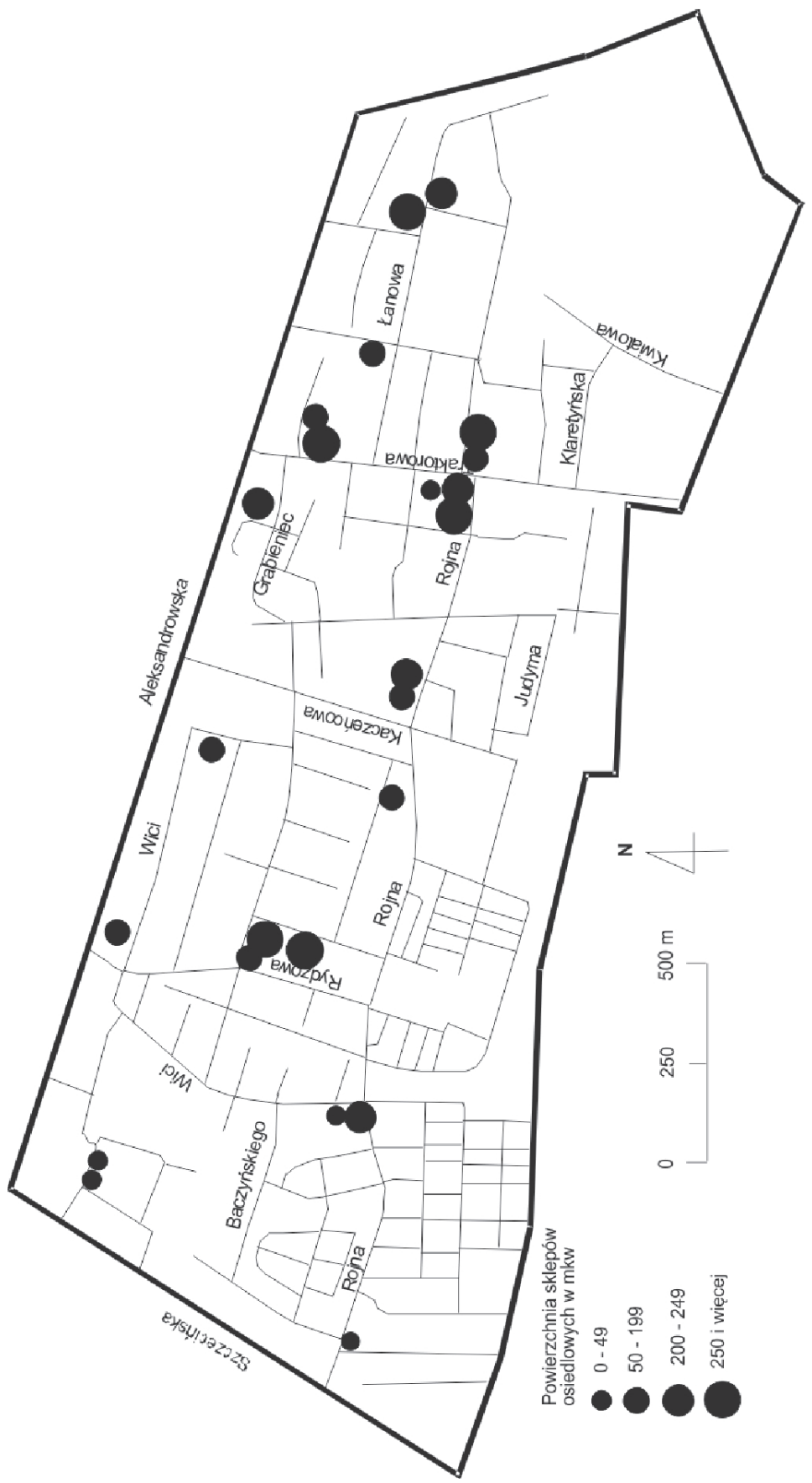

Rys.5. Powierzchnia sklepów osiedlowych na Teofilowie

Źródło: materiały zebrane przez A. Woźniak (2014); opracowanie własne 
Wielkość powierzchni badanych sklepów ma wpływ na liczbę ich stałych pracowników (rys. 6). Wzrost tej powierzchni przeważnie pociąga za sobą zwiększenie liczby pracujących. Najczęściej w omawianych sklepach pracują 3 osoby, a maksymalna liczba pracowników dochodzi do 10; zatem prawie wszystkie rozpatrywane punkty handlowe reprezentują kategorię małych podmiotów gospodarczych.

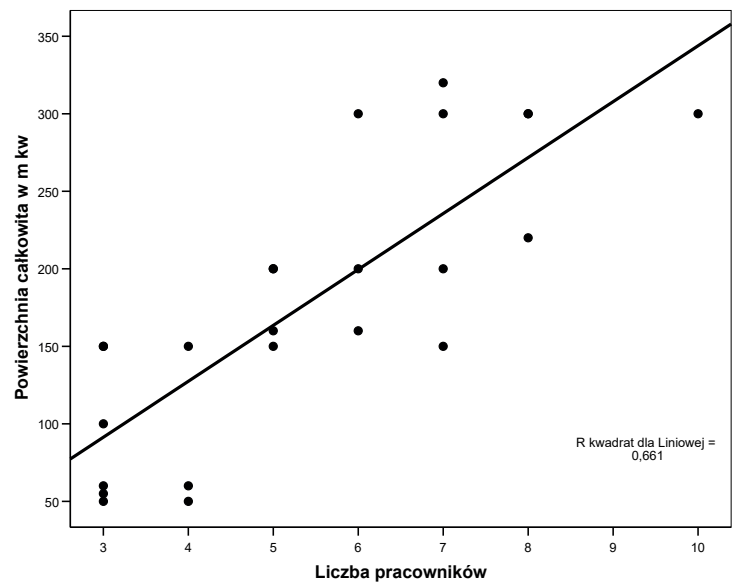

Rys. 6. Zależność pomiędzy powierzchnią całkowitą i liczbą pracowników w sklepach osiedlowych Teofilowa

Źródło: materiały zebrane przez A. Woźniak (2014); opracowanie własne

\subsection{Działalność handlowa sklepów}

Sklepy osiedlowe na Teofilowie zajmują się głównie sprzedażą różnorodnych produktów spożywczych, dobranych odpowiednio do potrzeb klientów. Kształtowanie asortymentu $\mathrm{w}$ tego rodzaju sklepach zależy m.in. od ich otoczenia, wielkości, formy sprzedaży, struktury klientów (Kucharska 2010). Ogół produktów oferowanych przez te sklepy dzieli się na trzy kategorie obejmujące asortyment podstawowy, uzupełniający i sezonowy. Asortyment podstawowy tworzą przede wszystkim różne artykuły spożywcze codziennego użytku. Do najbardziej reprezentatywnych z nich należą nabiał, produkty zbożowe (mąka, ryż, kasza, makarony itp.), tłuszcze (masło, olej), napoje, kawa i herbata, a także mięso i wędliny, mrożonki, przyprawy, sosy, keczupy, majonezy, musztardy. W skład asortymentu uzupełniającego wchodzą pieczywo, ciasta i ciasteczka, warzywa i owoce, papierosy, alkohole, artykuły chemiczne, kosmetyki, parafarmaceutyki, gazety i czasopisma. Warto przy tym zauważyć, że w porównaniu ze sklepami osiedlowymi szerszym wyborem pieczywa dysponują osiedlowe piekarnie, a większość świeżych warzyw i owoców dostarczają popularne warzywniaki lub małe targowiska. 
Charakterystycznym przykładem artykułów sezonowych są m.in. niektóre świeże owoce (np. truskawki, borówki, wiśnie, czereśnie) i warzywa (np. młode ziemniaki).

Badania terenowe (Woźniak 2014) wykazały znaczne zróżnicowanie asortymentu w sklepach osiedlowych Teofilowa. We wszystkich tych sklepach sprzedawane były takie artykuły, jak nabiał, produkty zbożowe, tłuszcze, ciasta i ciasteczka, słodycze, napoje, soki i wody mineralne, kawy i herbaty (rys. 7). Tyko nieliczne sklepy nie sprzedawały mięsa i drobiu, pieczywa, lodów i mrożonek, przypraw i sosów, papierosów i alkoholi. Natomiast znacznie więcej sklepów nie oferowało artykułów kosmetycznych, lekarstw bez recepty, ryb i owoców morza. Zaledwie w 25-30\% sklepów można zakupić warzywa, owoce, artykuły kosmetyczne i papiernicze.

Niektóre artykuły są sprzedawane w ściśle określonych miejscach poszczególnych sklepów. Regały z pieczywem, są ustawiane w miejscach najbardziej oddalonych od wejścia tak, aby klienci po drodze dokonywali innych zakupów. Obok tych regałów znajdują się zwykle lady chłodnicze z mięsem, wędlinami, serami i jogurtami. Tymczasem ciasta, ciasteczka, ryż, kasze i makarony umieszcza się na środkowych regałach, zapewniających dobrą ekspozycję. W pobliżu ustawione są chłodziarki z mrożonkami. Z kolei, w narożnych częściach sklepów pojawiają się regały $\mathrm{z}$ artykułami chemicznymi i kosmetykami, blisko kasy regały z napojami, a w dalszej od niej odległości alkohole. Przy samej kasie umieszcza się drobne produkty: cukierki, gumy do żucia, batoniki i parafarmaceutyki. Powinny one przyciągać uwagę klientów oczekujących w kolejce do kasy.

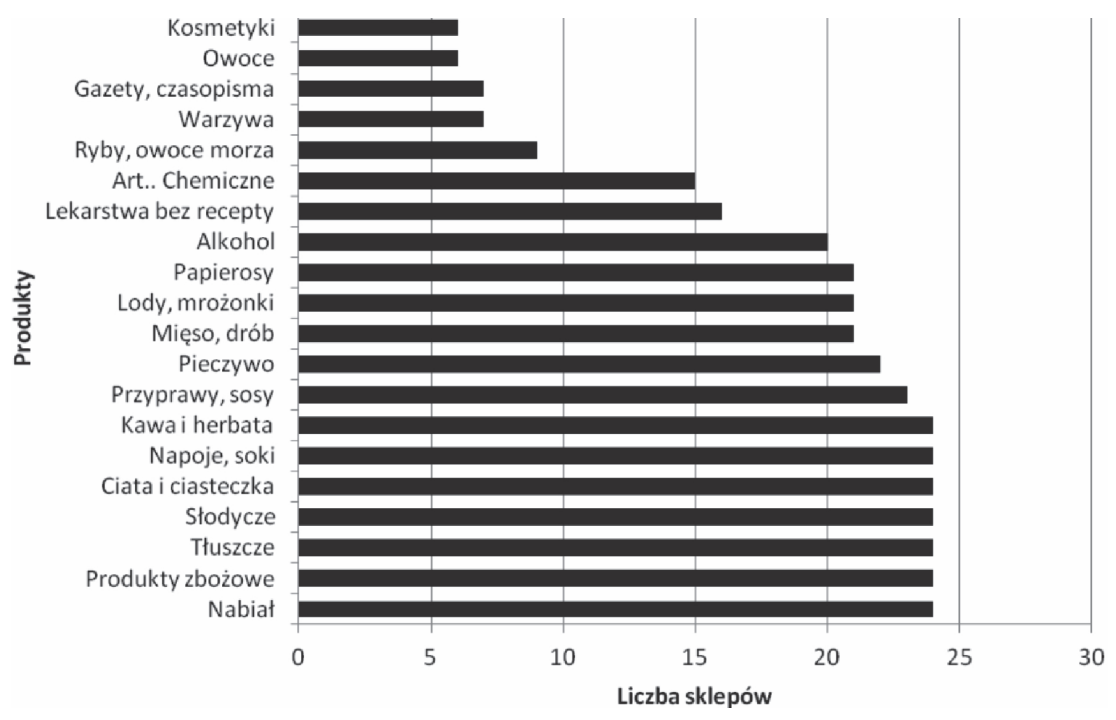

Rys. 7. Produkty sprzedawane w sklepach osiedlowych na Teofilowie Źródło: materiały zebrane przez A. Woźniak (2014); opracowanie własne 
Sklepy osiedlowe na Teofilowie, konkurując ze sklepami dyskontowymi, supermarketami i hipermarketami, w dni robocze są przeważnie otwarte przez 14 godzin - od godziny $6^{00}$ lub $7^{00}$ do godziny $20^{00}$ lub $21^{00}$. Różnica pomiędzy najdłużej i najkrócej pracującym sklepem wynosi osiem godzin. W soboty sklepy pracują o dwie godziny krócej, a różnica pomiędzy najdłuższym i najkrótszym czasem pracy zmniejsza się do sześciu godzin. Tylko 10 badanych sklepów pracuje w niedziele, najczęściej od godziny $9^{00}$ do $17^{00}$. Najdłużej otwartym (do godz. $24^{00}$ przez 18 godzin) sklepem osiedlowym na Teofilowie jest sklep ,Jędrek” położony przy ul. Rydzowej.

\section{Zachowania zakupowe i przestrzenne oraz opinie klientów sklepów osiedlowych}

\subsection{Struktura demograficzno-społeczna respondentów}

Analiza zachowań zakupowych i przestrzennych oraz opinii klientów sklepów osiedlowych na Teofilowie została oparta na przeprowadzonych w połowie 2012 roku sondażowych badaniach ankietowych 190 osób kupujących w tych placówkach handlowych (Woźniak 2014). Faktycznie dla celów analitycznych wykorzystano jedynie 141 poprawnie wypełnionych przez nich ankiet. Należy przy tym zaznaczyć, że zastosowanie dostępnościowego doboru respondentów znacznie ogranicza możliwości uogólniania wyników omawianych badań.

Struktura demograficzno-społeczna respondentów ma szereg specyficznych właściwości. W podziale ankietowanych według płci uwidacznia się znaczna przewaga liczebna kobiet nad mężczyznami (194 kobiety na 100 mężczyzn), co wiąże się z kultywowaniem przez mieszkańców Teofilowa tradycyjnych męskich i żeńskich ról społecznych. W przypadku struktury wieku można zauważyć zarówno bardzo wysoki udział osób w wieku produkcyjnym (49\%), jak też w wieku poprodukcyjnym (48\%), przy bardzo niskim odsetku osób w wieku przedprodukcyjnym (3\%). Tego typu struktura wieku została w dużej mierze ukształtowana wskutek długotrwałego procesu starzenia demograficznego całej ludności Teofilowa. Do najliczniejszych 10-letnich grup wiekowych wśród rozpatrywanych klientów należą grupa 70-79 lat (30\%) i 40-49 lat (24\%) (rys. 8). Dominującą grupą wiekową kobiet jest grupa 70-79 lat, a mężczyzn grupa 40-49 lat. Można przypuszczać, że mało liczni respondenci, reprezentujący mobilną kategorię wieku produkcyjnego (19-39 lat), preferują sklepy wielkopowierzchniowe. Typowy klient badanych sklepów osiedlowych wchodzi w skład dwuosobowych gospodarstw domowych (34\% respondentów). Za charakterystyczny należy też uznać wysoki udział respondentów tworzących jednoosobowe gospodarstwa domowe $(26 \%)$. 


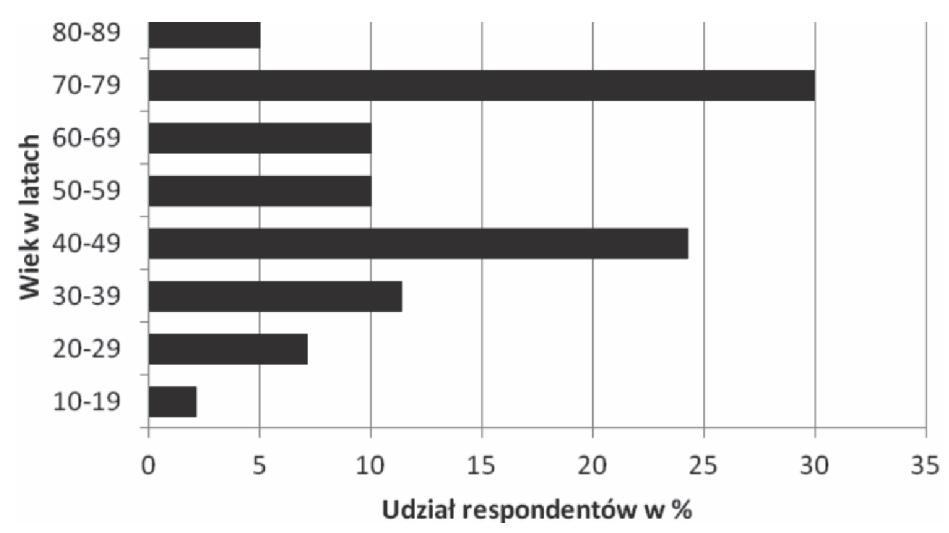

Rys. 8. Struktura wieku respondentów

Źródło: materiały zebrane przez A. Woźniak (2014); opracowanie własne

W strukturze wykształcenia ankietowanych największy udział (34,8\%) mają osoby z wykształceniem średnim ogólnokształcącym, natomiast w podziale źródeł utrzymania zaznacza się współdominacja utrzymujących się z emerytury $(42,6 \%)$ lub pracy zarobkowej $(41,8 \%)$. Do dominujących zawodów wykonywanych przez respondentów należą zawody związane głównie z handlem i usługami (21\%). Godny uwagi jest również fakt, iż większość respondentów (58,8\%) określało swój status materialny jako przeciętny.

\subsection{Zachowania zakupowe i przestrzenne klientów sklepów osiedlowych}

Zachowania zakupowe. Zachowania zakupowe i przestrzenne klientów sklepów osiedlowych wchodzą w zakres szerszego pojęcia zachowań konsumenckich, utożsamianych głównie z uzyskaniem i użytkowaniem produktów i usług. Na decyzje konsumenckie wywierają wpływ różnorodne czynniki psychiczne, społeczne i ekonomiczne. Same zachowania zakupowe odnoszą się do nabywania przez klientów danych produktów. Zachowania te można scharakteryzować biorąc pod uwagę: rodzaje nabywanych artykułów, częstość zakupów, czas ich trwania, wysokość wydatków ponoszonych na zakupy, samodzielne lub niesamodzielne dokonywanie zakupów.

Sklepy osiedlowe zaspokajają różnorakie potrzeby konsumpcyjne klientów. Ich zachowania zakupowe różnicują się przy tym w zależności od profilu danego sklepu. Na badanym obszarze występują cztery takie profile - ogólnospożywczy, spożywczo-warzywniczy, spożywczo-przemysłowy i spożywczo-alkoholowy. We wszystkich tych sklepach często kupowane są takie produkty spożywcze, jak pieczywo (60\% klientów), nabiał (50\%), warzywa i owoce (42\%). Produkty te należą do regularnie spożywanych. Czasem klienci kupują wyroby cukiernicze, mięsne, produkty zbożowe i napoje. Natomiast rzadziej nabywają papierosy 
i alkohole oraz artykuły chemiczne. Około $40 \%$ ankietowanych nigdy nie kupowało w analizowanych placówkach handlowych alkoholu lub papierosów, natomiast poniżej $10 \% \mathrm{w}$ ogóle nie nabywało tam mięsa, warzyw i owoców oraz artykułów chemicznych.

Częstość dokonywania przez klientów zakupów w badanych sklepach osiedlowych w przekroju tygodniowym jest duża i zarazem znacznie zróżnicowana. Za najbardziej typowych można uznać klientów (39\%), którzy udają się na zakupy do tych sklepów trzy razy w tygodniu. Zbliżony, dość wysoki udział (25\%) mają klienci, którzy realizują tam zakupy dwa lub cztery razy w tygodniu. Tylko niewielka część klientów dokonuje zakupów w takich sklepach jedynie raz w tygodniu, a także pięć lub sześć razy tygodniowo. Najczęściej w zakupach tych uczestniczą osoby wchodzące w skład dużych gospodarstw domowych. Im częściej klient odwiedza dany sklep osiedlowy, tym niższe są wydatki, które ponosi tam jednorazowo.

Typowy czas trwania zakupów realizowanych przez klientów sklepów osiedlowych nie jest długi, gdyż zawiera się w przedziale 11-20 minut (ponad 40\% ankietowanych). Stosunkowo liczną grupę stanowią też klienci przebywający w sklepie 6-10 minut (28\%) lub 5 minut i mniej (20\%). Znikomą rolę w strukturze czasu trwania zakupów pełnią zakupy długotrwałe (>20 min). Zazwyczaj im klient jest starszy, tym dłuższy czas przeznacza na zakupy. Ogólnie biorąc, dość krótki czas zakupów w badanej populacji wynika z braku kolejek, szybkiej obsługi, małej liczby kupowanych artykułów i dość dużej częstotliwości zakupów.

Przy częstych zakupach dokonywanych w sklepach osiedlowych jednorazowe wydatki z nimi związane są przeważnie niewysokie. Ponad połowa respondentów (52\%) deklarowała wydatki zawarte w przedziale $20-40 \mathrm{zl}$, a prawie $1 / 3(31 \%)$ wynoszące 40-60 zł. Nieduże wydatki wynikają w tym przypadku z faktu, że w sklepach osiedlowych realizowane są przede wszystkim zakupy niewielu, aktualnie niezbędnych, ale dosyć tanich produktów.

Zdecydowana większość klientów sklepów osiedlowych dokonuje zakupów samodzielnie (70\%), zazwyczaj w drodze z pracy do domu. Tylko $1 / 5$ respondentów robi zakupy wspólnie ze współmałżonkiem. Natomiast nieliczni respondenci w trakcie zakupów korzystają z pomocy własnych dzieci (5\%), wnuków lub innych osób (4\%). Realizowane zakupy są z reguły niewielkie, dlatego też przeważnie nie wymagają współudziału innych osób.

Zachowania przestrzenne. Zachowania przestrzenne klientów sklepów osiedlowych można rozpatrywać z różnych punktów widzenia. W tym opracowaniu wzięto pod uwagę rozmieszczenie miejsc zamieszkania tych klientów, liczebność tych miejsc, liczbę najczęściej odwiedzanych sklepów, motywy wyboru i czas dojścia do preferowanego sklepu, częstotliwość odwiedzania takiego sklepu, częstość korzystania ze sklepów osiedlowych w porównaniu ze sklepami wielkopowierzchniowymi. 
W rozmieszczeniu miejsc zamieszkania ankietowanych klientów sklepów osiedlowych na Teofilowie można zauważyć wyraźną tendencję do skupiania tych miejsc w pobliżu dużych kompleksów handlowo-usługowych oraz starszych i większych placówek handlowych (rys. 9). Stosunkowo mało klientów zamieszkuje w słabo zaludnionej strefie granicznej pomiędzy osiedlem Żeromskiego i Konopnickiej, a także na osiedlu Rogatka. Całkowity brak klientów cechuje rejony pozbawione zabudowy mieszkaniowej, gdzie z reguły znajdują się parki, ogródki działkowe i nieużytki.

Sklepy osiedlowe istniejące na Teofilowie różnią się liczbą klientów, na co wywiera wpływ silna konkurencja w tej grupie placówek handlowych i struktura przestrzenna ludności. Ze względu na zasięg oddziaływania, określony liczbą klientów, czołowe miejsce na badanym terenie zajmuje sklep spożywczy „Jędrek” położony na osiedlu Konopnickiej. Jest on jednym z najnowszych i zarazem najnowocześniejszych badanych sklepów. Oferuje szeroki asortyment, często niedostępny w innych sklepach, w tym żywność ekologiczną, dania obiadowe domowego wyrobu itp. Na drugim miejscu znalazł się „Nasz sklep” zlokalizowany na osiedlu Reymonta. Duży wybór artykułów spożywczych został tam wzbogacony o świeże produkty mięsne i wędliniarskie.

Wśród ankietowanych dominują (54\%) klienci dokonujący zazwyczaj zakupów w dwóch sklepach osiedlowych zlokalizowanych najbliżej ich miejsc zamieszkania. Tylko z jednego sklepu korzysta prawie $1 / 4$ respondentów, natomiast $1 / 5 \mathrm{z}$ nich dokonuje zakupów w trzech sklepach. Bardzo rzadko respondenci deklarowali korzystanie z większej liczby sklepów. Odwiedzanie przez większość respondentów tylko jednego lub dwóch sklepów osiedlowych wynika w szczególności z dogodnej lokalizacji tych punktów handlowych oraz utrwalonych przyzwyczajeń klientów.

Motywy wyboru preferowanego przez klienta sklepu osiedlowego są złożone. Najważniejszym motywem, deklarowanym przez $30 \%$ respondentów, okazało się dogodne położenie sklepu w stosunku do miejsca zamieszkania. Na drugim miejscu pod względem liczby wskazań (20\%) uplasował się duży wybór towarów oferowanych przez sklep. Mniejsze znaczenie dla ankietowanych miały takie równorzędnie potraktowane (po 13\%) powody, jak dobra jakość produktów, uprzejma obsługa i dogodne godziny otwarcia sklepu. Na wybór sklepu niewielki wpływ wywarły walory estetyczne sklepu, stałe rozmieszczenie produktów na regałach, niskie ceny artykułów, promocje i okresowe obniżki cen.

Należy podkreślić, iż badani klienci sklepów osiedlowych z reguły korzystają z placówek gwarantujących minimalizację czasu dojścia do danych obiektów. Przemawia za tym fakt, iż ponad $40 \%$ respondentów deklaruje czas wynoszący od 6 do 10 minut, a blisko 30\% ankietowanych czas 11-15 minut. Przeciętny czas dojścia do preferowanego sklepu osiąga zaledwie 11 minut. Jednocześnie stwierdzono, iż czas pokonywania drogi do określonego sklepu wzrasta wraz $\mathrm{z}$ wiekiem klienta. 


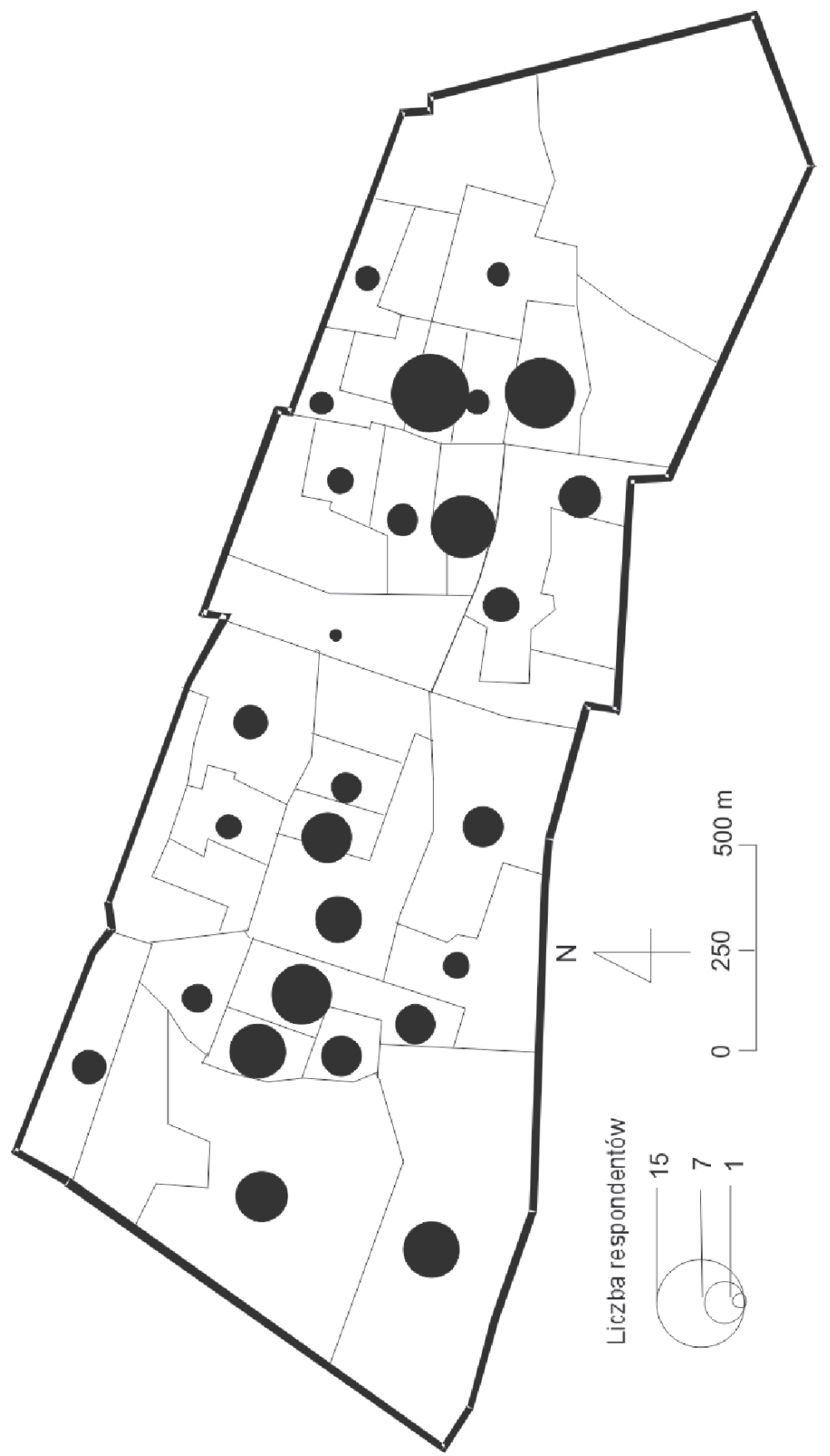

Rys. 9. Rozmieszczenie miejsc zamieszkania respondentów na Teofilowie według rejonów statystycznych

Źródło: materiały zebrane przez A. Woźniak (2014); opracowanie własne 
Biorąc pod uwagę dominującą częstotliwość korzystania przez respondentów z określonych rodzajów placówek handlowych można zauważyć, że sklepy osiedlowe uplasowały się na drugim miejscu, podczas gdy czołową pozycję zajęły małe targowiska i bazary (rys. 10). Zaobserwowano przy tym, że im starszy respondent, tym częściej dokonuje zakupów na rynku. Dla odmiany, im młodszy klient, tym bardziej preferuje zakupy w centrum handlowym. W ten sposób pośrednio uwidacznia się wpływ cen podstawowych artykułów żywnościowych stosowanych przez różne rodzaje obiektów handlowych, a także specyficznej struktury demograficzno-społecznej klientów na ich zachowania przestrzenne. Wśród badanych osób drugie miejsce pod względem częstości odwiedzin zajmują hipermarkety i supermarkety, a trzecie sklepy dyskontowe. Dodajmy, iż na pytanie, czy rozwój hipermarketów $i$ supermarketów na osiedlach mieszkaniowych zagraża istnieniu sklepów osiedlowych, aż $61 \%$ respondentów udzieliło odpowiedzi twierdzącej. Tylko $8 \%$ ankietowanych odpowiedziało na to pytanie negatywnie.

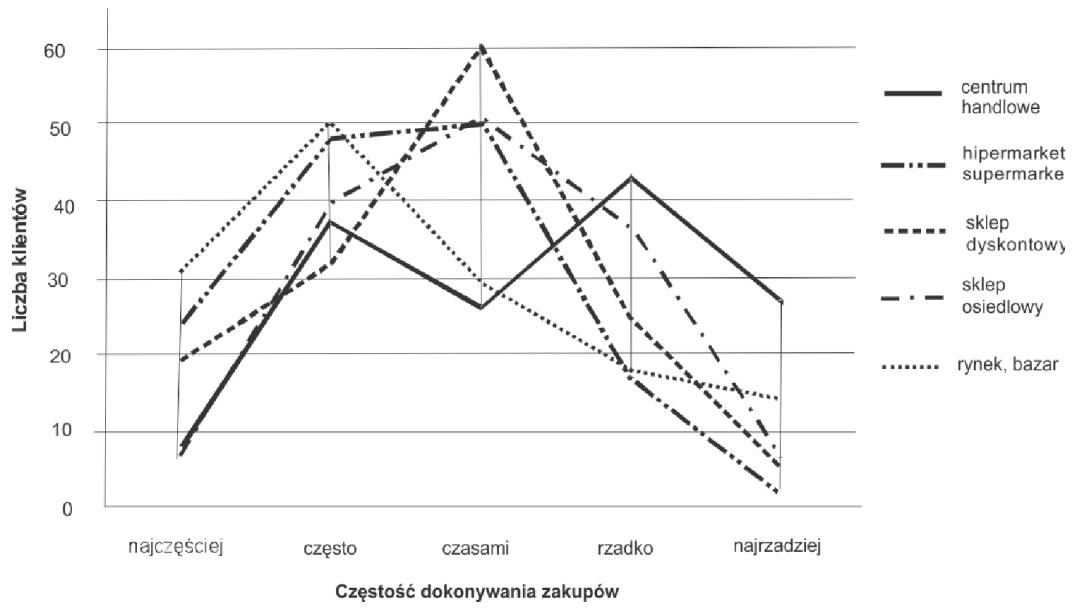

Rys. 10. Zakupy dokonywane przez respondentów na Teofilowie według form handlu Źródło: materiały zebrane przez A. Woźniak (2014); opracowanie własne

\subsection{Opinie klientów sklepów osiedlowych}

Opinie ankietowanych klientów na temat warunków funkcjonowania sklepów osiedlowych okazały się niejednoznaczne. Wzięto przy tym pod uwagę opinie odnoszące się do liczebności i lokalizacji tych sklepów, ich zalet i wad, cen oferowanych produktów, jakości sprzedawanych artykułów i jakości obsługi. Opinie dotyczące liczebności sklepów osiedlowych można uznać za korzystne dla sieci tych placówek. Okazało się bowiem, że aż 57\% respondentów oceniło tę liczebność jako odpowiednią w stosunku do potrzeb mieszkańców. Niemniej jednak zdaniem blisko $1 / 3(32 \%)$ ankietowanych jest ona zbyt mała. Te niekorzystne 
opinie formułowali przede wszystkim mieszkańcy nowszych osiedli mieszkaniowych, o słabiej rozbudowanej infrastrukturze społecznej. Dla odmiany znikoma część respondentów (3\%) uważa, że sieć sklepów osiedlowych Teofilowa została nadmiernie rozbudowana. Tego rodzaju opinie formułują w szczególności mieszkańcy środkowej części Teofilowa, gdzie występuje gęsta sieć handlu i usług. Warto też nadmienić, iż prawie, co 10 ankietowany nie potrafił sformułować swojej opinii w analizowanej kwestii.

Opinie respondentów w odniesieniu do lokalizacji sklepów osiedlowych są przeważnie pozytywne. Około $2 / 3$ badanych oceniło tę lokalizację korzystnie, a prawie ${ }^{1 / 5}$ bardzo korzystnie. Znikoma część ankietowanych uważa lokalizację badanych sklepów za niekorzystną (10\%) lub bardzo niekorzystną (2\%). Takie stanowisko może wynikać m.in. z uciążliwości towarzyszących działalności handlowej (np. nasilenie hałasu, ruchu komunikacyjnego i przestępczości). Znaczna dominacja pozytywnych opinii $w$ tym przypadku wiąże się z faktem, iż sklepy osiedlowe w zdecydowanej większości są położone blisko miejsc zamieszkania klientów. Godna uwagi jest także zbieżność takich opinii z bardzo wysokim udziałem respondentów deklarujących brak zamiaru zmiany systematycznie odwiedzanego sklepu osiedlowego $(94,3 \%)$. Nieliczni ankietowani deklarujący taki zamiar $(5,7 \%)$ za główną jego przyczynę podawali zmianę miejsca zamieszkania lub pracy, otwarcie konkurencyjnej placówki handlowej, niezadowolenie z obsługi w danym sklepie.

Sklepy osiedlowe według opinii mieszkańców Teofilowa mają wiele zalet i wad (w ankietach zaznaczano trzy główne). W przypadku zalet na pierwszy plan wysuwa się położenie blisko miejsca zamieszkania, wskazana przez ponad $30 \%$ respondentów. Na drugim miejscu pod względem częstości wskazań znalazł się krótki czas dokonywania zakupów (21\%), a na kolejnych miejscach miła i dostępna obsługa, dobra jakość produktów i trafnie dobrany asortyment (po ok. 15\%). Najmniej wskazań zostało przypisanych niskim cenom produktów, stałemu rozłożeniu towarów na półkach, dostępności lokalnych produktów, brakowi kolejek i możliwości parkowania blisko sklepu. Tymczasem za główne, prawie równoważne wady sklepów osiedlowych, najwięcej respondentów uznało brak promocji (26\%) i wysokie ceny (23\%). Mniej istotne wady, wskazane przez $10-15 \%$ badanych, stanowią: niewielki wybór i niska jakość produktów oraz brak samoobsługi. Do wad o znikomym znaczeniu, podanych przez mniej niż 10\% ankietowanych, należą: krótki czas otwarcia sklepu, jego nieestetyczny wygląd oraz nieprzystosowanie do potrzeb osób starszych i niepełnosprawnych.

Przeciętne ceny produktów sprzedawanych w sklepach osiedlowych Teofilowa najczęściej były oceniane przez respondentów (48,2\% ) jako wysokie. Niewiele mniejszy udział $(43,3 \%)$ mają klienci, którzy poziom tych cen uznali za średni. Kategorie bardzo wysokich oraz niskich i bardzo niskich cen były rzadko wskazywane przez ankietowanych (odpowiednio 3\%, 5\% i 0,5\%). 
Wśród respondentów dominują osoby (40\%) dobrze oceniające jakość towarów oferowanych przez badane sklepy. Zdecydowanie mniej klientów $(35,5 \%)$ uznało tę jakość za średnią. Natomiast stosunkowo niewielu wybierało pozostałe warianty oceny jakości towarów (bardzo wysoka, niska i bardzo niska).

Również jakość obsługi w sklepach osiedlowych najczęściej była dobrze oceniana przez ankietowanych (46,8\%). Znaczny udział $(35,5 \%)$ wśród nich mają też oceniający tę jakość jako średnią. Natomiast bardzo wysoka oraz niska i bardzo niska ocena jakości obsługi - podobnie jak w przypadku jakości towarów - była wskazywana przez pozostałą, niewielką część respondentów.

Uogólniając opinie badanych klientów sklepów osiedlowych zastosowano pięciostopniowy dyferencjał semantyczny (rys. 11 ). Odnosi się on do ocen sześciu wymiarów funkcjonowania tych placówek handlowych: utrzymania czystości, wyglądu sali sprzedażowej, jakości obsługi, wysokości cen, jakości produktów, zróżnicowania asortymentu. Dla każdego z tych wymiarów respondent mógł wybrać jedną z pięciu kategorii ocen. Uzyskane wyniki dowodzą umiarkowanego stopnia zróżnicowania opinii respondentów. Średnie oceny poszczególnych aspektów funkcjonowania sklepów oscylują blisko wariantu neutralnego (3). Najkorzystniejsze oceny dotyczą jakości obsługi. Nieco gorzej oceniono utrzymanie czystości, wygląd sklepu (zadbanie) i jakość produktów. Z kolei, negatywne oceny respondentów odnoszą się w szczególności do wysokości cen i zróżnicowania asortymentu. Zaobserwowano również, że różnice pomiędzy opiniami kobiet i mężczyzn są niewielkie.

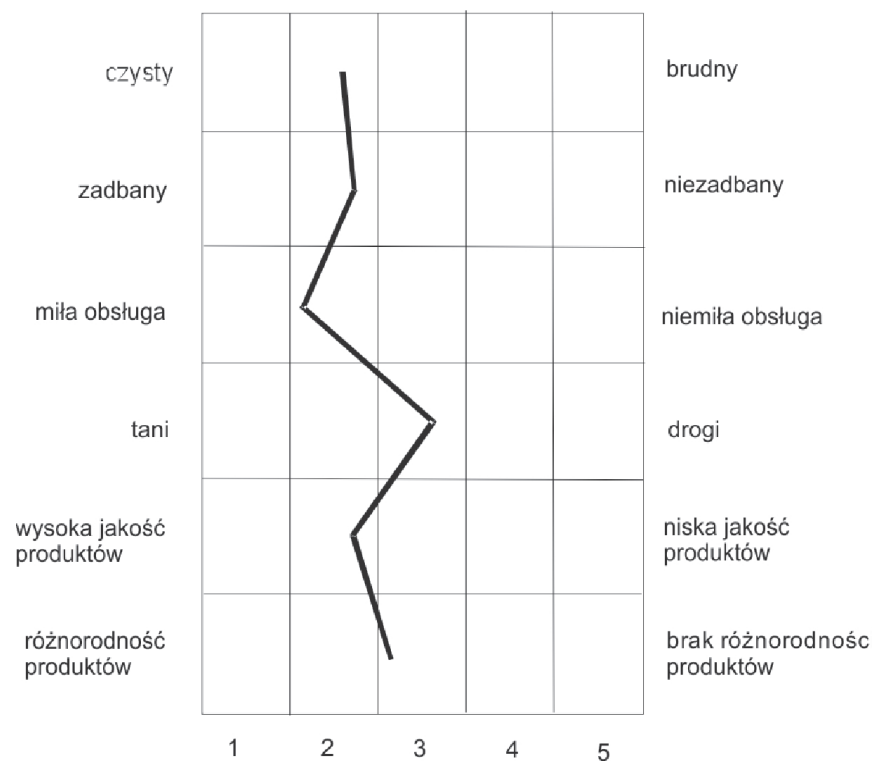

Rys. 11. Opinie klientów na temat funkcjonowania sklepów osiedlowych na Teofilowie Źródło: materiały zebrane przez A. Woźniak (2014); opracowanie własne 


\section{Podsumowanie}

Badaniom podlegały 24 sklepy osiedlowe zlokalizowane na terenie pięciu osiedli mieszkaniowych Teofilowa. Zespół tych osiedli położony jest w peryferyjnej, północno-zachodniej części Łodzi. Teren zajmowany przez rozpatrywane osiedla odznacza się długą i bogatą historią, która zdeterminowała ich układ przestrzenny. W ich zabudowie mieszkaniowej, pochodzącej w głównej mierze z lat 60 . XX wieku, przeważają czteropiętrowe bloki. Zwraca też uwagę dość dobrze rozwinięta infrastruktura techniczna i społeczna osiedli. Obecnie osiedla te zamieszkuje ok. 39 tys. osób.

Sklepy osiedlowe na Teofilowie są rozmieszczone nierównomiernie, podobnie jak ludność tej części miasta. Można przy tym wyróżnić trzy typy lokalizacji takich placówek handlowych: 1) lokalizacja na terenie dużych kompleksów handlowo-usługowych, 2) lokalizacja w niewielkich skupieniach różnego rodzaju sklepów, 3) lokalizacja w formie odosobnionych (rozproszonych) obiektów handlowych. Na ogólną i szczegółową lokalizację analizowanych sklepów wpływa wiele różnorodnych czynników.

Placówki handlowe na Teofilowie, których funkcjonowanie regulują określone przepisy prawne, nie są jednorodne. Typowa długość okresu prowadzenia przez nie działalności wynosi 12 lat, co dowodzi, że powstawały one przeważnie w okresie transformacji. Zaobserwowano przy tym, że sklepy zakładane w różnych okresach są inaczej rozmieszczone. Na całym Teofilowie dominują niewielkie sklepy osiedlowe należące do osób fizycznych, silniej rozproszone od pozostałych sklepów. Najczęściej w sklepie osiedlowym pracują tylko trzy osoby.

Badane punkty handlowe specjalizują się głównie w sprzedaży różnorodnych produktów spożywczych, dobranych odpowiednio do potrzeb klientów. Kształtowanie asortymentu w tego rodzaju sklepach zależy od ich wielkości, formy sprzedaży, struktury klientów, otoczenia itp. Badania terenowe wykazały znaczne zróżnicowanie tego asortymentu, przy czym we wszystkich sklepach sprzedawane były takie produkty, jak nabiał, artykuły zbożowe, tłuszcze, ciasta i ciasteczka, słodycze, napoje, soki i wody mineralne, kawy i herbaty.

Struktura demograficzno-społeczna ankietowanych klientów sklepów osiedlowych Teofilowa ma szereg specyficznych właściwości. Należy tutaj wymienić przewagę liczebną kobiet, współdominację osób w wieku produkcyjnym i poprodukcyjnym oraz tworzących jednoosobowe i dwuosobowe gospodarstwa domowe, względną przewagę liczebną osób z wykształceniem średnim ogólnokształcącym, współdominację utrzymujących się z emerytury i pracy zarobkowej, przeciętny status materialny większości respondentów.

Zachowania zakupowe badanych klientów różnicują się w zależności od profilu danego sklepu. Jednakże we wszystkich sklepach osiedlowych często kupowane są takie produkty spożywcze, jak pieczywo (60\% klientów), nabiał $(50 \%)$, 
warzywa i owoce, natomiast rzadziej - papierosy i alkohole oraz artykuły chemiczne. Za najbardziej typowych można uznać klientów, którzy udają się na zakupy do sklepów osiedlowych najczęściej trzy razy w tygodniu, przy czym przeciętny czas trwania zakupów zawiera się w przedziale 11-20 minut, a jednorazowe wydatki z nimi związane wynoszą 20-40 zł.

Zwraca uwagę tendencja do skupiania miejsc zamieszkania klientów rozpatrywanych sklepów osiedlowych w pobliżu dużych kompleksów handlowo-usługowych. Sklepy te różnią się liczbą klientów, na co wywiera wpływ silna konkurencja w tej grupie placówek handlowych i struktura przestrzenna ludności. Wśród ankietowanych dominują (54\%) klienci dokonujący zazwyczaj zakupów w dwóch sklepach osiedlowych zlokalizowanych najbliżej ich miejsc zamieszkania. Najważniejszymi motywami wyboru preferowanego sklepu okazały się jego dogodne położenie w stosunku do miejsca zamieszkania klienta i duży wybór oferowanych towarów. Przeciętny czas dojścia do preferowanego sklepu osiąga zaledwie 11 minut.

Przeprowadzone badania wykazały również, że opinie klientów na temat funkcjonowania sklepów osiedlowych są niejednoznaczne. Większość respondentów uznała liczebność, a także lokalizację tych sklepów za odpowiednią w stosunku do potrzeb mieszkańców. Sklepy osiedlowe w opinii klientów mają przy tym zarówno wiele zalet, jak i wad. Najwięcej klientów do głównych zalet tych sklepów zaliczyło położenie blisko miejsca zamieszkania i krótki czas dokonywania zakupów. Tymczasem za najważniejsze, prawie równoważne wady omawianych sklepów respondenci przeważnie uznali brak promocji i wysokie ceny. Spośród sześciu porównywanych wymiarów funkcjonowania sklepów osiedlowych korzystne oceny (przeciętne) dokonane przez klientów dotyczą jakości obsługi, utrzymania czystości, wyglądu sklepu (zadbanie) i jakości produktów. Z kolei, negatywne oceny respondentów odnoszą się do wysokości cen i zróżnicowania asortymentu.

Prezentowane wyniki badań wskazują, że silną konkurencję dla istniejących sklepów osiedlowych stanowią przede wszystkim sklepy wielkopowierzchniowe, a także handel internetowy. Od niedawna na rozwój badanych sklepów osiedlowych negatywnie wpływała ekspansja dyskontów. Obecnie na tereny analizowanych osiedli mieszkaniowych coraz częściej wkraczają małe sklepy sieciowe. Można przypuszczać, że również w najbliższych latach sklepy typu convenience będą najszybciej rozwijającym się segmentem detalicznego handlu osiedlowego. W tej chwili w szczególnie trudnej sytuacji znalazły się sklepy osiedlowe stanowiące własność osób fizycznych. Szansą na ich przetrwanie jest tworzenie dużych grup zakupowych, daleko idąca specjalizacja i zrzeszanie się w sieci. Równocześnie konieczne jest zwiększenie rentowności tych placówek handlowych. 


\section{LITERATURA}

Badziak K., Chylak K., Łapa M., 2014, Łódź wielowyznaniowa. Dzieje wspólnot religijnych do 1914 roku, Wydawnictwo UŁ, Łódź.

Baranowski B., Fijałek J. (red.), 1980, Łódź. Dzieje miasta, t. 1: Do 1918 r., PWN, Warszawa-Lódź.

Boguszewicz-Kreft M., 2009, Zarządzanie doświadczeniem klienta w usługach, Wydawnictwo UG, Gdańsk.

Budner W., 2003, Lokalizacja przedsiębiorstw, AE w Poznaniu, Poznań.

Budner W., 2004, Lokalizacja przedsiębiorstw: aspekty ekonomiczno-przestrzenne iśrodowiskowe, AE, Poznań.

Budner W., 2011, Współczesne tendencje i determinanty lokalizacji handlu $w$ miastach, „Zeszyty Naukowe”, 21, WSHiU, Poznań, s. 52-60.

Chwałek J., 2008, Handel detaliczny, [w:] Szulce H., Chwałek J., Ciechomski W., Mielczarczyk Z., Ekonomika handlu. Podręcznik, cz. 1, WSiP, Warszawa, s. 18-186.

Czuba M., 2001, Marketing ustug. Teoria i praktyka, Wydawnictwo TARA, Katowice.

Daszkowska M., 1998, Ustugi: produkcja, rynek i marketing, PWN, Warszawa.

Daszkowska M., 2005, Marketing ustug - wybrane aspekty, Wydawnictwo Naukowe US.

Dylikowa A., 1973, Geografia Polski. Krainy geograficzne, PZWS, Warszawa.

Dzieciuchowicz J. (red.), 2005, Ustugi rynkowe $w$ Łodzi $w$ dobie transformacji, Wydawnictwo UŁ, Łódź.

Dzieciuchowicz J., 2011, Środowisko mieszkaniowe wielkiego miasta. Przykład Łodzi, Wydawnictwo UŁ, Łódź.

Dzieciuchowicz J., 2012, Wielkie centrum handlowe $w$ przestrzeni miejskiej i podmiejskiej. Manufaktura w Łodzi i Ptak w Rzgowie, Wydawnictwo UŁ, Łódź.

Dzieciuchowicz J., 2013, Handel w przestrzeni wielkomiejskiej. Przykład Łodzi, Wydawnictwo UŁ, Łódź.

Dzieciuchowicz J., 2014, Ludność Łodzi. Rozwój i przemiany strukturalne, Wydawnictwo UŁ, Łódź.

Godlewska H., 2001, Lokalizacja działalności gospodarczej. Wybrane zagadnienia, WSH i FM, Warszawa.

Godlewska H., 2005, Lokalizacja w zarządzaniu przedsiębiorstwem, PW-H GRAF, Warszawa.

Ilnicki D., 2009, Przestrzenne zróżnicowanie poziomu rozwoju ustug w Polsce. Teoretyczne i praktyczne uwarunkowania badań, UW, Wrocław; Rozprawy naukowe Instytutu Geografii i Rozwoju Regionalnego Uniwersytetu Wrocławskiego.

Kaczmarek T., 2010, Struktura przestrzenna handlu detalicznego. Od skali globalnej do lokalnej, Bogucki Wydawnictwo Naukowe, Poznań, s. 196-235.

Kondracki J., 2002, Geografia regionalna Polski, PWN, Warszawa.

Koter M., 2012, Relikty osadnictwa przedprzemystowego $i$ dziewiętnastowiecznego na planie współczesnej Łodzi, [w:] Liszewski S., (red.), Atlas Miasta Łodzi, Suplement 2, plansza LXI, Urząd Miasta Łodzi, Łódzki Ośrodek Geodezji, Łódź.

Kramer T., 2000, Podstawy marketingu, PTE, Warszawa.

Kucharska B. (red.), 2010, Obstuga klienta w przedsiębiorstwie handlu detalicznego, Wydawnictwo AE, Katowice. 
Liszewski S. (red.), 2009, Łódź. Monografia miasta, ŁTN, Łódź.

Mazurek-Łopacińska K., 2003, Zachowania nabywców i ich konsekwencje marketingowe, PWE, Warszawa.

Mikołajczyk B., Stolecka A., 2009, Wybrane aspekty zmian w ustugach w Polsce - diagnoza i prognoza, [w:] Rudawska I., Soboń M. (red.), Przedsiębiorstwo i klient w gospodarce opartej na ustugach, Wydawnictwo Difin, Warszawa.

Rogoziński K., 2000, Ustugi rynkowe, Wydawnictwo AE, Poznań.

Rudawska I. (red.), 2009, Ustugi w gospodarce rynkowej, PTE, Warszawa.

Rudnicki L., 2012, Zachowania konsumentów na rynku, PWE, Warszawa.

Sygulski M., 2003, Historia Bałut, t. 1, Kolonizacja, Wydawnictwo Ameba, Łódź.

Sygulski M., 2006, Historia Bałut, t. 2, Osada Bałuty Nowe. Ludność - zabudowa-posesje, Wydawnictwo Ameba, Łódź.

Szromik A., 2010, Marketing terytorialny. Miasto i region na rynku, Wolters Kluwer Polska, Warszawa.

Szulce H., 1998, Struktury $i$ strategie w handlu, PWE, Warszawa.

Światowy G., 2006, Zachowania konsumentów, PWE, Warszawa.

Wieloński A., 2004, Lokalizacja działalności gospodarczej. Teoretyczne podstawy, Wydawnictwo Przemysłowe WEMA, Warszawa.

Wilk W., 2001, Czynniki lokalizacji i rozmieszczenie wybranych ustug $w$ Warszawie, WG i SR UW, Warszawa.

Williamson A., Mullin R., 2011, Field marketing. Skuteczne zastosowania marketingu terenowego, Wolters Kluwer Polska, Warszawa.

Woś J., Rachocka J., Kasperek-Hoppe M., 2011, Zachowania konsumentów - teoria i praktyka, Wydawnictwo UE w Poznaniu, Poznań.

Woźniak A., 2014, Lokalizacja i funkcjonowanie sklepów osiedlowych na Teofilowie w Ło$d z i$, KGPiPP UŁ, Łódź.

\section{THE COMMUNITY SHOPS: LOCATION AND ACTIVITY AS WELL AS PURCHASE AND SPATIAL BEHAVIOURS OF THEIR CUSTOMERS. EXAMPLE TEOFILÓW IN LÓDŹ}

Summary: Area occupied by housing estates on Teofilów and their spatial arrangement, as well as distribution and functioning of community shops are characterized by long and rich history which determined them. In case these housing estates, originating in the main measuring cup from years 60 . of the $20^{\text {th }}$ century, four-storey blocks predominate. A quite well-developed technical and social infrastructure also pays attention. At present c 39 thousand persons inhabit these housing estates.

Community shops on Teofilów are distributed unevenly, similarly to the population of this part of the city. It is possible in addition to distinguish three types of the location of such retail outlets: 1) location on the area of great commercial-service complexes, 2) location in little concentrations of shops of different kind, 3) location of commercial objects in the form isolated. Many diverse factors influence the general and detailed localization of analyzed shops.

Community shops on Teofilów, of which specific provisions of law govern functioning, aren't homogeneous. The typical length of the period of conducting activity by them is 
12 years. It establishes that they came into existence mainly in the period of the transformation. We observed in addition that founded shops differently were distributed in different periods. On entire Teofilów dominate little community shops belonging to natural persons, more strongly dispersed from remaining shops. In the community shop only three persons most often work.

Explored commercial points specialize mainly in the sale of diverse products food, selected appropriately to needs of customers. Shaping the assortment in that kind of shops depends on their size, form of the sale, structure of customers, surrounding and the like Field examinations demonstrated considerable diversifying this assortment, in addition in all shops such products were sold, like eggs and dairy products, cereal articles, the canailles, cakes and cookies, drinks, juices and mineral waters, coffees and teas. Some articles are deposited in closely determined places of individual shops. One should also mark, that community shops, competing with large-surface shops, mainly are opened in working days as far as by 14 hours. However the majority of these shops don't work on Sundays.

Demographic-social structure of polled customers of community shops Teofilów has a number of peculiar properties. One should here exchange numerical superiority of women, co-dominance of persons in an working and post-working age and building households single and consisting of two persons, relative numerical superiority of persons with the secondary school secondary education, co-dominance the keeping oneself from the retirement pension and the paid work, average financial status of the majority of respondents.

Purchase behaviours of examined customers diversify depending on the outline of the given shop. However in all community shops such food products are often bought, like the bread ( $60 \%$ of customers), eggs and dairy products $(50 \%)$, vegetables and fruits, but rarely - cigarettes and alcohol and chemical articles. Too most typical it is possible to regard customers which independently to community shops most often go to the shopping three times during the week, in addition the time of lasting the shopping is included in a period from 11 up to 20 minutes, and disposable expenses associated with them amount to $20-40 \mathrm{PLN}$.

A tendency of concentrating places of residence of customers of considered community shops in the vicinity of big commercial-service complexes pays attention. These shops differ in the number of customers what the strong competition exerts influence in this group of retail outlets on and spatial structure of the population. Amongst respondents dominate $(54 \%)$ customers committing the shopping in two community shops located closest their places of residence usually. Most important motives for choice of preferred shop turned out to be his convenient location towards a place of residence of the customer and a large range of offered goods. The average time of the approach for the preferred shop achieves only 11 minutes. Taking into consideration the greatest frequency of using by respondents retail outlets of different kind, it is possible to notice that community shops positioned themselves on the second place, while small marketplaces and markets filled the leading position.

Conducted examinations also showed that opinions of customers about functioning of community shops were ambiguous. The majority of respondents recognized the number, as well as the localization of these shops too proper towards needs of residents. Community shops in the opinion of customers have both a lot of virtues, and defects in addition. 
The most customers ranked the closeness of a place of residence and the short time of making purchases among main advantages of these shops. Of shops meanwhile for most important, almost equivalent defects discussed respondents mainly recognized the lack of the promotion and ceiling prices. Out of six compared dimensions of functioning of community shops beneficial evaluations (averages) made by customers qualities concern service, keeping the purity, the appearance of the shop (taking care) and qualities of products. Next, negative assessments of respondents refer up to prices and diversifying the assortment.

Presented research findings indicate, that for further functioning of existing community shops above all large-surface shops constitute a considerable risk. Also a competition increases from the side of small shops belonging to new networks, as well as the Internet trade. Therefore the role of community shops in the everyday shopping of food products can significantly reduce. All the same thanks to their established virtues community shops have a raison d'être in the future.

Presented research findings indicate, that for existing community shops above all large-surface shops, as well as an Internet trade constitute the strong competition. Negatively an expansion of discount shops only recently affected the development of inspected community shops. At present network small shops more and more often enter areas of analysed housing estates. It is possible to suppose in the nearest years shops of the type convenience will also be a most quickly developing section of the retail community trade. At the moment community shops constituting the property of natural persons were in particularly a difficult situation. Creating purchase largest groups, the far-reaching specialization and forming a union in the web are a chance of surviving them. At the same time increasing the profitability of these retail outlets is necessary.

Key words: community shops, purchase and spatial behaviors customers, space city, Łódź.

Dr hab. Jerzy Dzieciuchowicz, prof. UŁ Emerytowany prof. UŁ Wydział Nauk Geograficznych, Uniwersytet Łódzki 